\title{
I. Haçlı Seferinde Türkiye Selçuklu Sultanı I. Kılıç Arslan'ın Uyguladığı Savaş Taktikleri ve Türk Ordusunun Savaşçılık Özellikleri Hakkında Bir Değerlendirme
}

\author{
Kerim Köksal KAYA \\ Doktora öğrencisi, Ankara Hacı Bayram Veli Üniversitesi, Lisansüstü Eğitim Enstitüsü, Orta Çağ Tarihi Ana Bilim Dalı, \\ Ankara, Türkiye, kerimkoksalkaya@gmail.com (Sorumlu Yazar/Corresponding Author)
}

\section{Sinan TARIFCI}

Arş. Gör. Dr., Giresun Üniversitesi, Fen-Edebiyat Fakültesi, Tarih Bölümü,

Giresun, Türkiye, sinantar@ hotmail.com

\begin{tabular}{|c|c|}
\hline Makale Bilgileri & ÖZ \\
\hline $\begin{array}{l}\text { Makale Geçmişi } \\
\text { Geliş: 07.11.2021 } \\
\text { Kabul: } 15.12 .2021 \\
\text { Yayın: } 31.12 .2021 \\
\text { Anahtar Kelimeler: } \\
\text { Türkler, } \\
\text { Türkiye Selçukluları, } \\
\text { I. Kilıç Arslan, } \\
\text { I. Haçlı Seferi, } \\
\text { Haçlılar. }\end{array}$ & $\begin{array}{l}\text { XI. yüzyıl sonlarında Batı Avrupa Hristiyan dünyası, Kudüs'ü kurtarmak sloganıyla Türkleri Anadolu'dan } \\
\text { atmak ve Orta Doğu'ya hâkim olan İslâm dünyasına kastetmek maksadıyla harekete geçmişti. Önce disiplinsiz } \\
\text { ve düzensiz Haçlı öncüleri, ardından da profesyonel asıl Haçlı orduları, arkalarındaki kalabalık halk kütleleriyle } \\
\text { birlikte İstanbul üzerinden Anadolu'ya girmişlerdir. Selçuklu Türkleri de kısa bir süre önce gelip yerleştikleri } \\
\text { Anadolu'da Haçlı istilasına karşı bir vatan savunmasına girişmek durumunda kalmışlardır. Türkiye Selçuklu } \\
\text { sultanı I. Kılıç Arslan başkomutanlığındaki Türk orduları Haçlılara karşı Anadolu'da başlıca meydan, kuşatma, } \\
\text { savunma ve gerillâ savaşları vermiştir. Türkler, her biri farklı nitelikleri haiz olan bu savaş tülerinin } \\
\text { gerektirdiği bütün faaliyet ve unsurlardan olabildiğince yararlanmışlardır. Türkler ve Haçlılar arasındaki çetin } \\
\text { mücadelelerde insan, teşkilat ve teçhizat olmak üzere maddî bakımdan orduyu oluşturan temel unsurların } \\
\text { yanında, pek çok manevî unsur da karşı karşıya gelmiştir. Bu çalışmada I. Haçlı seferinde vuku bulan } \\
\text { Kserigordon kuşatması (1096), Kırkgeçit (Drakon) baskını (1096), İznik savunması (1097) ve Eskişehir } \\
\text { (Dorylaion) meydan savaşı (1097) çerçevesinde Türkiye Selçuklu sultanı I. Kılıç Arslan'ın uyguladığı savaş } \\
\text { taktikleri ve Türk ordusunun savaşçllı özellikleri hakkında birtakım değerlendirmeler yapılacaktır. }\end{array}$ \\
\hline
\end{tabular}

\section{An Review on the Warfare Tactics of Qilij Arslan I, the Sultan of the Seljuqs of Rūm and the Military Characteristics of the Turkish Army in the First Crusade}

\begin{tabular}{|c|c|}
\hline Article Info & ABSTRACT \\
\hline $\begin{array}{l}\text { Article History } \\
\text { Received: } 07.11 .2021 \\
\text { Accepted: } 15.12 .2021 \\
\text { Published: } 31.12 .2021 \\
\text { Keywords: } \\
\text { the Turks, } \\
\text { the Seljuqs of Rūm, } \\
\text { Qilij Arslan I, } \\
\text { the First Crusade, } \\
\text { the Crusaders. }\end{array}$ & $\begin{array}{l}\text { At the end of the 11th century, the Christian world of Western Europe took action with the slogan of liberating } \\
\text { Jerusalem, to expel the Turks from Anatolia and to damage the Islamic world dominating the Middle East. First } \\
\text { the disorderly vanguards of the Crusaders, and then the professional armies entered Anatolia. The Seljuqs had } \\
\text { to engage in a homeland defense against the Crusaders in Anatolia, where they settled a short time ago. Turkish } \\
\text { armies under the command of Qilij Arslan I, the Sultan of the Seljuqs of Rūm, made pitched, siege, defensive } \\
\text { and guerrilla warfare against the Crusaders. The Turks benefited from all the activities and factors required by } \\
\text { these war types, each of which has different characteristics. In the uphill struggles between the Turks and the } \\
\text { Crusaders, besides the main factors that constitute the army in material terms, including people, organization } \\
\text { and equipment, many spiritual elements faced also each other. In this study, as part of the siege of Xerigordos, } \\
\text { the raid of Drakon, the defense of Nicaea and the Battle of Dorylaion in the First Crusade, some evaluations } \\
\text { will be made about the warfare tactics of Qilij Arslan I and the military characteristics of the Turkish army. }\end{array}$ \\
\hline
\end{tabular}

Atıf/Citation: Kaya, Kerim Köksal - Tarifci, Sinan. “I. Haçı Seferinde Türkiye Selçuklu Sultanı I. Kılıç Arslan’ın Uyguladığı Savaş Taktikleri ve Türk Ordusunun Savaşçılık Özellikleri Hakkında Bir Değerlendirme”. Selçuklu Medeniyeti Araştırmaları Dergisi (SEMA) 6 (Aralık 2021), 55-70. https://doi.org/10.47702/sema.2021.15 


\section{GİRIŞ}

Amacı galip gelmek olup tarafların askerî kuvvetlerinin giriştikleri silahlı mücadele demek olan savaşlar türüne, özelliğine, kullanılan silahlara, savaşçıların sayısı ve niteliğine, uygulanan taktik ve stratejilere göre belli başlı türlere bölümlenmektedir. I. Haçlı seferinde ${ }^{1}$ Haçlı ordularına karşı Türkiye Selçuklu sultanı I. Kılıç Arslan başkomutanlığındaki Türk ordularının başlıca savaş türlerinden meydan, kuşatma, savunma ve gerillâ savaşlarına giriştiği görülmektedir. Meydan savaşı, adından da anlaşılacağı üzere, iki rakip ordunun geniş bir alanda yaptı̆̆ savaştır. Bu tür savaşın en temel özelliği, kati sonuçlu olmasıdır. Meydan savaşları genellikle birkaç saatte sonuçlanır, bazen de birkaç gün sürebilirdi. Yine bu savaşlar genelde uzaktan ok atışlarıyla başlar, yakın dövüş silahlarıyla göğüs göğüse çarpışmaya kadar varırdı. Türkler meydan savaşlarında birtakım taktik ve stratejiler uygulard1. Bunlar başlıca stratejik mevkileri ve hâkim tepeleri tutma, sürpriz baskın ve hücum düzenleme, uzaktan savaşma, sahte ricatla düşmanı pusuya düşürme gibi faaliyetlerdi. Türkler İznik önlerinde ve Eskişehir'de Haçlılara karşı meydan savaşına girişmişlerdir. Kuşatma savaşı, hedef kale veya şehrin ele geçirilmesi amacıyla yapılan savaştır. Sur, hendek gibi savunma yapılarının yanı sıra deniz, göl, ırmak, dağ gibi doğal engellerle de çevrili olan Orta Çağ kale ve şehirlerini düşürebilmek hayli güç idi. Kuşatma savaşlarında sonuç elde etmek günler, haftalar, aylar ve hatta yıllar alabilirdi. Türkler birçoğunu açık alanlarda yaptıkları savaşlarda olduğu gibi, kuşatma savaşlarında da sürpriz baskın, düşmanı abluka altına alma, kuşatılan şehir ve kaleye casus sokarak karışıklık çıkarma, gizlice kaleye sızma, düşmanı kandırma ve yanıltma vb. yıpratma ve yıldırma faaliyetleri icra ederlerdi ${ }^{2}$. İlk Haçlı grubuna karşı girişilen Kserigordon kuşatması kapsamlı ve uzun zaman süren bir kuşatma olmasa da kuşatma savaşlarının temel özelliği olan düşmanı fiziksel ve psikolojik olarak yıldırma ve yıpratma faaliyetleri hususunda bir örnek teşkil etmektedir. Savunma savaşı, kuşatma savaşına karş1 yapılan savaşların bütünüdür. Diğer bir ifadeyle, saldırı halinde bulunan düşmana karşı alınan muhafaza durumudur. Savunma yapılarıyla çevrelenmiş ve savunma silahlarıyla donatılmış sarp ve müstahkem kale veya şehirlerin içi, uzun süren kuşatmalara karşı dayanabilmek için silah, cephanelik, yiyecek, içecek gibi savaş ve yaşam malzemeleriyle dolu olurdu. Türkler Haçlılar karşısında İznik’te savunma savaşı vermişlerdir. Gayrinizami bir savaş olan gerillâ savaşı, yani vurkaç taktiğiyle birden saldırıp hemen kaybolmak suretiyle savaş, düzenli ordulardan ziyade profesyonel askerlerden müteşekkil hafif teçhizatlı ve küçük birliklerle yapılan savaştır. Gerillâ savaşında, sayı ve teçhizat bakımında üstün olan düşman karşısında birlikleri boşu boşuna kırdırmamak ve sürpriz baskın, pusu ve umulmadık hamlelerle düşmana önemli kayıplar verdirmek hedefi güdülürdü․ Bununla birlikte Türklerin dikkate değer savaş özelliklerinden birisi, düzenli ordu savaşından gerillâ savaşına veya

\footnotetext{
${ }^{1}$ Haçlı seferleri ve bu arada I. Haçlı seferi hakkında başlıca mesela bk. Thomas Asbridge, Haçlı Seferleri, çev. Ekin Duru (İstanbul: Say Yayınları, 2014); Claude Cahen, Haçlı Seferleri Zamanında Doğu ve Batı. çev. Mustafa Daş (İstanbul: Yeditepe Yayınevi, 2016); Malcolm Barber, Haçlı Devletleri Tarihi, çev. Doğan Mert Demir (İstanbul: Kronik Kitap, 2021); Carole Hillenbrand, Müslümanların Gözünden Haçl Seferleri, çev. Nurettin Elhüseyni (İstanbul: Alfa Yayınlar1, 2015); Peter Frankopan, The First Crusade: The Call from the East. Massachusetts: Belknap Press of Harvard University Press, 2012; Riley-Smith, Jonathan. The First Crusade and the Idea of Crusading. London: Continuum, 2003).

2 Salim Koca, Selçuklular'da Ordu ve Askerî Kültür (Ankara: Berikan Yayınevi, 2005), 171, 173-178. Haçlı seferlerinde Haçlılar ve Müslümanlar tarafindan gerçekleştirilen kuşatmalar ve kuşatma savaşları hususunda müstakil bir inceleme için ayrıca bk. Aydın Usta, Haçlı Seferlerinde Kuşatma (İstanbul: Yeditepe Yayınevi, 2015).

3 Türkler pek çok büyük savaşa çıkmadan evvel gerillâ savaşlarıyla düşmanı hırpalama faaliyetlerine girişmişlerdir. Bu faaliyetin temeli dinamizm ve ok atma yeteneğine dayanmaktadır (Erkan Göksu, Türkiye Selçuklularında Ordu (Ankara: Türk Tarih Kurumu Yayınları, 2010), 216-217). Örneğin, Selçukluların Gaznelilere karşı Dandanakan meydan savaşını yapmadan önceki bütün askerî faaliyetleri ve Bizans'a karşı Malazgirt meydan savaşını yapmadan önceki Anadolu'da yaptığı bütün askerî harekâtları gerillâ savaşı türündedir.
} 
I. Haçlı Seferinde Türkiye Selçuklu Sultanı I. Kılıç Arslan'ın Uyguladığı Savaş Taktikleri ve Türk Ordusunun Savaşçılık Özellikleri Hakkında Bir Değerlendirme

gerillâ savaşından düzenli ordu savaşına hızlı bir şekilde geçiş yapabilmesidir ${ }^{4}$. I. Haçlı seferinde bu savaş dinamizmini pek çok kez görmek mümkündür. Özellikle Eskişehir meydan savaşından sonra Sultan I. Kılıç Arslan, Haçlılarla mevcut şartlar altında meydan savaşı yapmanın mümkün olmadığını anlamış ve süratle ordusunu gerillâ türü savaş için düzenlemişti.

Batı'da Türklerin savaşçılık niteliklerine dair söylemler, henüz ilk Haçlı seferi vuku bulmadan evvel başlamıştı. Ancak bu söylemler olumsuz bir Türk imgesi etrafinda şekillenmişti. Haçlı seferlerini başlatmak için öncelikle bir orduya ihtiyaç vardı. Bu orduya Avrupalı Hristiyan halkı dâhil etmek için somut argümanların yanı sıra, bazı hayalî argümanların kullanılması gerekliydi. Haçlı seferlerinin temellerinin atıldığı Clermont Konsili'nde Papa II. Urbanus, Türkleri olumsuz imgelerle nitelerken, onların savaşçılık özelliklerine de değinmişti. Buna göre, Türkler art arda yaptığı seferlerle Marmara kıyılarına kadar ulaşmışlar ve yedi kez Hristiyanları yendikleri gibi, birçok esirler almışlar ve hatta kiliseleri yok etmişlerdi ${ }^{5}$. Daha bu kayıttan, sürekli gelişen seferlere bağlı olarak, Türklerin başlıca savaşç1ık özelliklerinden dinamizm vurgulanmıştır. Hatta mezkûr konsilde Türkler hakkında abartılı ifadeler dile getirenler de olmuştur. Mesela St. Remi Manastırı keşişlerinden Robert, Türklerin istilacı ve yağmacı olduğunu; bununla da kalmayarak her şeyi yakıp yıkıp, yok eden ve insanlara ağır işkenceler uygulayan zalimler olduğunu ifade etmiştir ${ }^{6}$. Haçlıların Türklerin savaşçılıklarına dair bu yöndeki ilk duyum ve izlenimleri bir yana, daha ilk Haçlı öncülerinden itibaren Türk başkomutanlarının ve ordularının yalnız yağma ve tahribata girişmekten ibaret oldukları düşünülen faaliyetlerinden ziyade, profesyonel bir şekilde uyguladıkları askerî taktik ve stratejiler ile üstün silah kullanma yetenekleri Haçlilar tarafından idrak edilecektir.

\section{Kserigordon Kuşatması (1096)}

Türklerin Haçlı öncülerini kuşattı̆̆ı ilk yer İznik yakınlarında bulunan Kserigordon adı verilen terk edilmiş bir kaledir. Bu kale muhkem bir konumda olmasına rağmen su kaynağı bakımından yetersiz durumdaydı. Bu nedenle mezkûr kalede savunma yapacak olanlar suyu kalenin dişından temin etmek zorundayd1 ${ }^{7}$. Anonim Gesta müellifi, bu kalenin hem metruk hem de içinde bol yiyecek olduğunu ifade etmiştir. Metruk bir kalede bol miktarda yiyecek bulma ihtimalinin zayıf olduğu göz önüne alındığında Türklerin, Haçlıları tuzağa çekmek adına bir pusu kurmuş olmaları ihtimal dâhilindedir ${ }^{8}$. Ayrıca Albertus Aquensis, bu kalenin Türklere ait olduğunu belirtmekle bu ihtimali kuvvetlendirmektedir? .

İlk Haçlı grupları bu kaleyi, etrafa yapacakları akınlar için askerî üs yapmayı planladılar ve buraya yerleştiler. Bu durumu haber alan Türkiye Selçuklu sultanı I. Kılıç Arslan, derhal ya kardeşi Melik Davud'u (Kulan Arslan) ya da İlhan unvanlı ordu komutanını kaleyi Haçlılardan tekrar alması için görevlendirdi ${ }^{10}$. Türk ordusu kale önünde görüldü. Haçlı liderlerinden Reinald, kuvvetlerini

\footnotetext{
${ }^{4}$ Koca, Selçuklular'da Ordu ve Askerî Kültür, 181; Muharrem Kesik, At Üstünde Selçuklular: Türkiye Selçukluları'nda Ordu ve Savaş (İstanbul: Timaş Yayınları, 2014), 206.

${ }^{5}$ Fulcherius Carnotensis, Kudüs Seferi, çev. İlcan Bihter Barlas (İstanbul: IQ Kültür Sanat Yayıncılık, 2009), 5051.

${ }^{6}$ Dana Carleten Munro, Urban and Crusaders (Philadelphia, Pa.: The Department of History of the University of Pennsylvania, 1901), 5-6.

${ }^{7}$ Steven Runciman, Haçlı Seferleri Tarihi, çev. Fikret Işıltan (Ankara: Türk Tarih Kurumu Yayınları, 2008), $1 / 101$.

${ }^{8}$ Anonim Haçlı Tarihi, çev. Ergin Ayan (İstanbul: Selenge Yayınları, 2013), 53, dipnot 101.

${ }^{9}$ Albertus Aquensis, Historia Ierosolimitana: History of the Journey to Jerusalem, İng. çev: Susan B. Edgington (Oxford: Oxford Medieval Text, 2007), 33.

${ }^{10}$ Haçlıların ilk gruplarıyla yapılan savaşlarda Türkiye Selçuklu ordusunun başında Anna Komnena'ya göre İlhan unvanlı bir komutan, İbnü'l-Kalânisî’ye göre Sultan I. Kılıç Arslan'ın kardeşi Melik Davud bulunuyordu (Osman Turan, Selçuklular Zamanında Türkiye (İstanbul: Ötüken Neşriyat, 2004), 129).
} 
I. Haçlı Seferinde Türkiye Selçuklu Sultanı I. Kılıç Arslan'ın Uyguladığı Savaş Taktikleri ve Türk Ordusunun Savaş̧̧ılık Özellikleri Hakkında Bir Değerlendirme

pusuya yatırmış ve Türkleri tuzağa çekmeye çalışmışsa da bunda başarılı olamadı ve kaleye kapandı ${ }^{11}$. $\mathrm{Bu}$ andan itibaren Türklerin yürüttüğü kuşatma faaliyeti ve taktikleri hakkında bazı değerlendirmeler yapmak mümkündür. Haçlılar kaleye kapanınca Türk ordusunun buraya bir taarruz yapmadığı; kalenin su ihtiyacını karşılayacak olan iki kaynağı tutmakla iktifa ettiği dikkat çekmektedir. Türkler kale içine yerleştirdiği bir miktar erzakla Haçlıları kendilerini bir süre savunabileceklerine inandırmış görünmektedir. Ancak Haçlilar Kserigordon'da sadece sekiz gün direnebilmişler ve bu süre sonunda teslim olmak zorunda kalmışlardır. Anonim Gesta'nın kaydettiğine göre, Haçlılar burada inanılmaz bir su kıtlığı yaşamıştı. Öyle ki, Haçlıların bir kısmı at ve eşeklerinin damarlarını kesmiş ve buradan elde edilen kanı içmiş; başka bir kısmı üzerlerindeki kıyafetleri çıkarıp kalenin kanalizasyonunda ıslattıktan sonra, bundan elde ettikleri suyu; bununla da kalmayarak idrarlarını içmişlerdi ${ }^{12}$. Bu savaş, Türklerin ilk Haçlıları psikolojik anlamda hem bir yıkıma uğrattığı ve hem de çözümlediği bir savaş durumundadır. Bu çözümleme neticesinde Sultan I. Kılıç Arslan, Haçlıları kendi istediği istikamete çekerek yapılacak bir sürpriz baskınla yok edebileceğini anlamış olmalı ki Kırkgeçit adı verilen yerde bu yönde hazırlıklarına başlamıştı.

\section{Kırkgeçit (Drakon) Baskını (1096)}

Kırkgeçit’te yapılacak sürpriz baskının ilk adımı olarak Sultan I. Kılıç Arslan, Kserigordon kuşatmasından hemen sonra Haçlıların karargâhına iki casusunu yollayarak Haçlıların İznik'i aldığı ve Türklerden büyük bir ganimet ve zafer elde ettiği gibi asılsız bir haberi Haçlılar arasında yayd1 ${ }^{13}$. Kılıç Arslan bu şekilde davranarak Haçlıların bir yandan tamahkâr ruhlarına dokunmaya, öte yandan cesaretlenerek gururlanmalarını, rehavete kapılarak Türkleri hafife almalarını ve harekete geçmelerini sağlamaya çalıştığı görülmektedir. Zira Kılıç Arslan, Anna Komnena'nın belirttiği üzere, Haçlıların ganimete düşkünlügünü biliyordu ${ }^{14}$. Sultan Kılıç Arslan, Haçlıların bu zafiyetini kendi lehinde kullanmak gayesiyle harekete geçmişti ${ }^{15}$. Türk ordusu Haçlıların geçme ihtimali olan yolları, geçitleri tutmuş olmakla birlikte ${ }^{16}$; Kılıç Arslan, bu yollar ve geçitler üzerinde kendi belirlediği ve tuzaklar kurduğu istikametten Haçlıları savaş alanına çekmek istiyordu. Gerçekten de casusların Haçlı karargâhında yaydıkları haberin asılsız olduğu Haçlılar tarafından öğrenilene dek Haçlılar büyük bir heyecana kapılmıştı ve Civetot'taki Haçlı karargâhında elde edilecek ganimetlerden pay almak ve zengin olmak arzusuyla derhal sefere çıkmak isteyenlerin sayısı oldukça fazlayd ${ }^{17}$. Hal böyle olunca durum tam da Sultan Kılıç Arslan'ın planladığı gibi gelişmiş ve bazı Alman Haçlılar ordugâhtan ayrılarak büyük hırslarla, güya İznik'i ele geçiren soydaşlarına katılmak için yola çıkmışlardı. Bu Haçlı grubu Kılıç Arslan'ın yollarda ve geçitlerde kurduğu pusulara düşmüşlerdi. İşin aslı Haçlılar tarafından öğrenilince de Haçlı karargâhında heyecanın yerini kargaşa, öfke, panik, korku ve nefret duyguları almışt1 ${ }^{18}$. Böyle bir ortamda Haçlı liderleri karargâhta ihtilafa düşmüştü. Buna göre, Haçlı komutanlarının bir kısmı fevrî hareketlerden kaçınmak ve sabırla hareket edilmesi gerektiğini savunurken, özellikle piyade komutanı Godefroi Burel başta olmak üzere, bir kısım Haçlı lideri derhal

\footnotetext{
${ }^{11}$ Runciman, Haçl Seferleri Tarihi, 101.

${ }^{12}$ Anonim Haçlı Tarihi, 53; Runciman, Haçlı Seferleri Tarihi, 101.

${ }^{13}$ Anna Komnena, Alexiad, çev. Bilge Umar (İstanbul: İnkılap Kitabevi, 1996), 307; Runciman, Haçlı Seferleri Tarihi, 101; Işıın Demirkent, Haçll Seferleri (İstanbul: Dünya Yayıncılık, 2013), 17.

${ }^{14}$ Anna Komnena, Alexiad, 307.

${ }^{15}$ Salim Koca, Türkiye Selçukluları Tarihi: Sultan Alp Arslan'dan Uluğ Keykubad'a (1071-1220)(Ankara: Berikan Yayınevi, 2016), 101.

${ }^{16}$ İbn Kalânisî, Şam Tarihine Zeyl: I. ve II. Haçlı Seferleri Dönemi, çev. Onur Özatağ (İstanbul: Türkiye İş Bankası Kültür Yayınları, 2015), 1.

${ }^{17}$ Runciman, Haçl Seferleri Tarihi, 101.

${ }^{18}$ Willermus Tyrensis, Willermus Tyrensis'in Haçlı Kroniği: Başlangıçtan Kudüs'ün Zaptına Kadar, çev. Ergin Ayan (İstanbul: Ötüken Neşriyat, 2016), 67; Albertus Aquensis, Historia Ierosolimitana, 37; Kesik, At Üstünde Selçuklular, 114.
} 
I. Haçlı Seferinde Türkiye Selçuklu Sultanı I. Kılıç Arslan'ın Uyguladığı Savaş Taktikleri ve Türk Ordusunun Savaşçılık Özellikleri Hakkında Bir Değerlendirme

Türklere savaşmak gerekliliğini savunuyordu. Nihayet Haçlıların ikinci görüşü ağır bastı. Haçlı ordusu geride sadece çocuklar, kadınlar ve silah taşımaya muktedir olmayan diğer kişileri bırakarak 25 bin yaya ve 500 tam teçhizatlı süvari ile toplamda altı birliğe taksim edilmiş halde karargâhlarından harekete geçerek Drakon vadisi olarak da bilinen ve yollarına pusular kurulan Kırkgeçit mevkiine girdiler ${ }^{19}$. Kırkgeçit mevkiinin dağlık ve ormanlık bir vadi olduğu göz önüne alındığında, Türkiye Selçuklu ordusunun sürpriz baskın için uygun bir konumda pusu kurduğu açıktır. Albertus Aquensis, Emîr Süleyman olarak kaydettiği Sultan Kılıç Arslan'ın bu ani hücumdan hemen önce askerlerinin morallerini yükseltmek ve onların cesaretlerini artırmak için bir nutuk irat ettiğini ifade etmiştir ${ }^{20} . \mathrm{Bu}$ nutukta o, Haçlılara karşı avantajlı durumda olunduğundan, olabildiğince çabuk ve sessiz bir şekilde konuşlanıp sürpriz baskının yapılması gerektiğinden, böylece düşmanın sığınabilecek herhangi bir yer bulamayacağından bahsetmiştir ${ }^{21}$.

Haçl1ların Kırkgeçit mevkiine nara ve gürültülerle girmesine karşılık Türk ordusu, kendi savaş taktiğine uygun olarak, olabildiğince hızlı ve sessiz bir şekilde mevzilenmişti ${ }^{22}$. Bu durum, Türklerin sürpriz baskınlarının iki temel vasfını da gözler önüne sermektedir: Sürat ve sessizlik. Türk ordusu etrafına pusular kurduğu ormanlık vadinin ortasında görününce Haçlıların, içinde 500 şövalyenin yer aldığ 1 iki birliği saldırı için harekete geçmiştir. Bu esnada Haçlı ordularının beklemediği bir şekilde Türkler ormanlar arasından ok taarruzuyla ilk hamlesini yapmışlardır. Bu hamleyle birlikte iki Haçlı birliği ciddi kayıplar vermiş; bunun yanı sıra geride kalan dört Haçlı birliğinden tamamen kopmuştur $^{23}$. Bu sırada Haçlıların yaptıkları bir hamleyle 200 kadar Türk askerinin hayatını kaybetmesi neticesinde, aynı vasıtayla, fakat farklı bir strateji hızlıca uygulanmıştır. Bu da ok atışlarının ağır zırhlarla bürülü olan düşman askerlerinden ziyade, onların atlarına yapılmasıdır. Böylece vadi ortasında hedef alınarak yere düşürülen veya sağa sola kaçırılan atlar kontrolden çıkmışlar ve ortamdaki kargaşa son hadde ulaşmıştır. Selçuklu birlikleri için zaten topluca pusuya düşürülmüş olan, yaşanan kargaşa ortamıyla birlikte ayrıca yaya kalan ve kaçışan Haçlıları yok etmek zor olmamıştır ${ }^{24}$.

\section{3. İznik Savunması (1097)}

İznik'in kaybı Türklerin Haçlılar karşısında aldığı ilk ağır darbe idi. İznik savunması birbirleriyle doğrudan ilişkili ve birbirlerinin tamamlayıcısı durumunda olan eksik istihbarat, rehavet ve yanılgı gibi birtakım stratejik hatalar sebebiyle Kılıç Arslan'ın başında bulunduğu Türkiye Selçuklularının mağlubiyetiyle neticelenmiştir. İlk olarak sultan, bu zamana kadar gösterdiği istihbarat başarısını tüm çabalarına rağmen burada sağlayamamıştır. Her ne kadar İstanbul'da asıl Haçlı kuvvetlerinin toplandığını ve takribi olarak nicelikleri hakkında haber aldıysa da gelen bu kuvvetlerin

19 Anna Komnena, Alexiad, 306; Runciman, Haçlı Seferleri Tarihi, 101-102; Willermus Tyrensis, Willermus Tyrensis 'in Haçlı Kroniği, 68; Albertus Aquensis, Historia Ierosolimitana, 39.

${ }^{20}$ Nutuk irat etme, Türklerin savaştan önce gerçekleştirdikleri bir savaş geleneğidir. Bundaki amaç, askerlerin savaş azmini artırmak, onları coşturmak suretiyle ordunun manevî cephesini takviye etmektir. Türk ordusunu psikolojik manada savaşa hazırlayan nutuk atma geleneğinin pek çok örneği Türk tarihinde mevcuttur. Sultan Alp Arslan Malazgirt zaferi öncesinde, Gazi Umur Bey Mora seferinin öncesinde, hatta yüzylllar sonra Gazi Mustafa Kemal Atatürk Başkomutanlık meydan savaşında askerlerinin halet-i ruhiyelerine uygun nutuklar irat ederek onları coşturmuşlardır.

${ }^{21}$ Albertus Aquensis, Historia Ierosolimitana, 39, 41.

${ }^{22}$ Albertus Aquensis, Historia Ierosolimitana, 39, 41.

${ }^{23}$ Albertus Aquensis, Historia Ierosolimitana, 41.

${ }^{24}$ Willermus Tyrensis, Willermus Tyrensis’in Haçlı Kroniği, 68; Demirkent, Haçlı Seferleri, 18; Runciman, Haçlı Seferleri Tarihi, 102. Albertus Aquensis, Historia Ierosolimitana, 41. Kırkgeçit (Drakon) savaşı ile ilgili ayrıca mesela bk. Birsel Küçüksipahioğlu, "Türklerle Haçlıların İlk Karşılaşması: Drakon Savaşı”, Tarih ve Uygarlık İstanbul Dergisi 4 (Aralık 2013), 43-51; Erkan Göksu, "Haçlıların Anadolu'daki İlk Faaliyetleri ve Kırkgeçit (Drakon) Savaşı (1096)”, Ekev Akademi Dergisi 39 (Bahar 2009), 363-370. 
I. Haçlı Seferinde Türkiye Selçuklu Sultanı I. Kılıç Arslan'ın Uyguladığı Savaş Taktikleri ve Türk Ordusunun Savaşçılık Özellikleri Hakkında Bir Değerlendirme

nitelikleri hakkında mutlak bilgiler elde edememiştir ${ }^{25}$. Yeterli ve güvenilir istihbaratın elde edilememesi, Sultan I. Kılıç Arslan’1 bazı hatalara ittiği görülmektedir. Bu hatalardan birisi, sultanın disiplinsiz ve düzensiz Haçlı öncülerine ${ }^{26}$ karşı Kserigordon ve Kırkgeçit’te elde edilen başarılardan dolayı rehavete kapılması ve asıl Haçlı ordusunun kuvvetini öngörememesidir. Bu durum uzun vadede Türkiye Selçuklu Devletinin ve hatta Anadolu'daki Türk varlığının geleceğini tehlikeye sokmakla birlikte, kısa vadede Haçlı ordularının küçümsenmesiyle ikinci bir stratejik hatanın yapılmasına neden olmuştur $^{27}$. İkinci hatalı strateji, Sultan I. Kılıç Arslan'ın Ermenilerin elinde bulunan Malatya'yı ele geçirmek için doğuya doğru sefere çıkmasıdır. Bu şekilde İznik’ten oldukça uzak kalmıştır. Ayrıca sultanın Malatya seferine çıkarken aile bireylerini ve hazinesini İznik’te bırakmış olması, Haçlıların İznik’i ele geçireceklerine dair ihtimalin pek düşünülmediğini de göstermesi bakımından önemlidir ${ }^{28}$. Anna Komnena'nın “İznik’ten sultana çağrı gönderip duruyorlardı.” kaydı, I. Kılıç Arslan'a birden fazla yardım çağrısı gittiğini gösterir. Anlaşılan, Sultan Kılıç Arslan kapıldığı rehavetin etkisiyle gelen bu çağrıları ilk başlarda ciddiye almamıştı. Ancak daha sonra sultan, İznik'ten gelen yardım çağrılarının ısrarıyla öncü kuvvet olarak bir keşif birliğini göndermiş ve ardından Malatya kuşatmasını kaldırarak bizzat harekete geçmiştir. Sultanın gönderdiği keşif birliği İznik kuşatmasındaki Haçlı ordularının durumu hakkında birtakım bilgiler elde ederek sultana ulaştırmıştır ${ }^{29}$. Her ne kadar güvenilir ve yeterli istihbarat elde edilemediyse de kuşatmayı anlatan kaynaklar incelendiğinde, Sultan I. Kılıç Arslan'ın sefer ve savaş öncesi istihbarata ve düşmanı değerlendirmeye son derece önem verdiği anlaşılmaktadır. Sultan özellikle İznik civarına gelip konumlandığında İznik'le sürekli bir irtibat kurmaya çalışmış, birden fazla mektuplaşma ${ }^{30}$ faaliyetine girişmiştir. Sultanın iki casusuyla İznik'e gönderdiği, ancak yolda Haçlıların eline geçen mektuplardan birisi dikkat çekicidir. Willermus Tyrensis'in kaydettiği bu mektubun değerlendirmesini yapmadan evvel buraya nakli yerinde olacaktır:

"Şehrimizi kuşatıp almak isteyen bu barbarlar önünde artık korkmayın. Kuvvetli, cesur ve kalabalık orduyla yakınlarınızda bulunuyoruz ve arkamızdan kalabalık orduların yardıma gelmesi ve birleşerek onların ordugâhlarına hücum etmemiz yakındır. Bu nedenle biz dışarıdan hücum ederken, kapıları tutmaya ve bize yardım etmeye hazır olun. Onların kalabalıklığı karşısında korkmayın; onlar çok uzaklardan, güneşin battığı yerden geliyorlar. Uzun yolculuktan dolayı yorgun ve bitkin olan savaşçılar ve yüklerini taşıyan atları bizim taze kuvvetlerimizle mukayese edilemez. Sizler onlardan çok sayıdakilere karşı nasıl kolayca zafer kazandığımızı, bir günde onlardan 50 bin kişiyi imha

25 İstanbul'da toplanan asıl Haçlı orduları düklerin, kontların yönetiminde, çoğunluğu şövalyelerden oluşan birliklerdi. Fransa Kralının kardeşi Hugue de Vermandie, Lorraine Dükü Godefroi de Bouillon ve kardeşi Baudouin, Toulouse Kontu Raymond, Flandr Kontu Robert ve Norman reisi Bohemund ve yeğeni Tankred bunların başında gelmekteydi (Koca, Türkiye Selçukluları Tarihi: Sultan Alp Arslan'dan Uluğ Keykubad'a (1071-1220), 101; Işın Demirkent, "İznik'in Haçlılar Tarafından Kuşatılması (6 Mayıs-19 Haziran 1097)" Haçlı Seferleri Tarihi: Makaleler, Bildiriler, İncelemeler (İstanbul: Dünya Yayıncılık, 2012), 30.

${ }^{26} \mathrm{Bu}$ Haçlı grupları düzenli ve profesyonel bir orduda bulunması gereken unsur ve vasıflara sahip değildi. Salim Koca, bu Haçlılara "çapulcu sürüsü” yakıştırması yapmıştır (Koca, Türkiye Selçukluları Tarihi: Sultan Alp Arslan'dan Uluğ Keykubad'a (1071-1220), 99).

${ }^{27}$ Tamara Talbot Rice, Anadolu Selçuklu Tarihi, çev. Tuna Kaan Taştan (Ankara: Nobel Akademik Yayıncılık, 2015), 51.

${ }^{28}$ Runciman, Haçlı Seferleri Tarihi, 135-136; Demirkent, Haçlı Seferleri, 29, 32; Işın Demirkent, Türkiye Selçuklu Hükümdarı Sultan I. Kılıç Arslan (Ankara: Türk Tarih Kurumu Yayınları, 2014), 28.

${ }^{29}$ Anna Komnena, Alexiad, 325-326; Albertus Aquensis, Historia Ierosolimitana, 103.

${ }^{30}$ Sultan Kılıç Arslan'ın Haçlı ordusuna karşı giriştiği harekâtın başarısız olması neticesinde İznik’te bulunan Türklere "başlarının çaresine bakmaları"nı ifade eden bir mektup daha göndermiş olması, arada birden fazla mektuplaşmanın gerçekleştiğini göstermektedir. 
I. Haçlı Seferinde Türkiye Selçuklu Sultanı I. K1lıç Arslan'ın Uyguladığı Savaş Taktikleri ve Türk Ordusunun Savaşçılık Özellikleri Hakkında Bir Değerlendirme

ettiğimizi bizzat hatırlarsınız. Cesaretlenin ve endişelenmeyin; çünkü sabahleyin yedinci saatten önce size yardım edilecek ve düşmandan kurtulacaksınız ${ }^{31}$."

Bu mektup, İznik'e ulaşamadan Haçlıların eline geçmiş olmakla birlikte, Kılıç Arslan tarafından İznik'teki Türklere gönderilmiş ilk mektup olmalıdır. Mektup, iki temel özelliği haiz görünmektedir. İlk olarak, İznik savunucularını cesaretlendirmek ve onların özgüvenlerini arttırmak için birtakım ifadeleri barındıran bir nutuk mahiyetindedir. İkinci olarak mektup, Sultan Kılıç Arslan'ın Haçlılar hakkındaki değerlendirmesi ve onlara karşı yapılacak harekâtın bir planı mahiyetindedir. Ayrıca rehavetin yansımalarını mektupta geçen birtakım ifadelerden görmek mümkündür. Bütün bunların ötesinde, kanaatimizce kuşatmanın kırılma noktasını oluşturan vaka, bu mektubun ve Türk casuslarının Haçlıların eline geçmesidir. Zira Haçlılar yakaladıkları Türk casuslarının birini öldürmüşler; ötekini sorguya çekmişlerdi. Bu sorguda Haçlılar, Sultan Kılıç Arslan'ın dağa konumlandığını, saldırı zamanını ve planını öğrenmişler; tedbirlerini buna göre planlamışlardı. Yani sultan savaş emri verdiğinde, Haçlılar gafil durumda değildi ${ }^{32}$.

Bütün bunlara rağmen Sultan Kılıç Arslan, yanında Karaca ve Buldacı gibi Türk emîrleriyle birlikte daha önce elde ettiği istihbarata dayanarak ordusunu etraftaki dağlarda konumlandırıp İznik'e hâkim bir mevkiden Haçlı ordusuna saldırıp en az zayiatla kuşatmayı yarmayı planlamıştı ${ }^{33}$. Nihayet sultan, Toulouse kontunun tuttuğu kapıya doğru 10 bin kișilik bir süvari kuvvetine iki koldan harekât emrini verdi ${ }^{34}$. Bu harekâtta rol oynayan askerlerin en dikkat çeken dört özelliği sürat; hareketlilik; saldırı veya savunma durumunda at üstünde öne, arkaya, sağa ve sola, yukarıya ve aşağıya olmak üzere çok yönlü atıcılık; keskin nişancılıktır. İlk olarak Türkler, atları üzerinde son derece süratleniyorlar ve silah ve teçhizatlarından dolayı ağır hareket eden Haçlılara kendilerine yetişme imkânı tanımıyorlardı. İkinci olarak, hamlelerini büyük bir hareketlilikle gerçekleştiriyorlardı. Üçüncü olarak, düşmanın hangi yönden geldiğinin bir önemi olmaksızın onlara her durumda zayiat vermek için yay ve oktan olabildiğince fazla istifade etmeye çalışıyorlardı. Son olarak onlar, bütün bu sürat, hareket ve at üstünde çok yönlü atıcılıkla hedefleri tam isabetle vurmaktalardı. Türklerin bu dört meziyeti bir araya getirip başarıyla uygulayabilmelerinin manevî unsurları onların yaşam tarzı ve savaş tecrübeleri ise de maddî unsurları zırhlarının ve silahlarının hafif ve atlarının çevik ve süratli olmasıdır. Bu özelliklere ve savaş anlayışına sahip Türkiye Selçuklu ordusunun savaş düzeni ise dağınık düzendi. Yani Türkiye Selçuklu askerleri bir arada durmuyorlard ${ }^{35}$. Zaten toplu düzene geçmiş bir ordunun, sürati ve hareket kabiliyeti sınırlı olacağından, yukarıda zikredilen özellikleri gösterebilmesi pek mümkün olamaz. Bu bakımdan Türklerin dağınık düzeni aslında onların savaș meydanında olabildiğince özgür bir savaş anlayışıyla savaştığını göstermektedir. Sayıca çok üstün durumda olan Haçlı kuvvetleri metal teçhizatlı, ağır silahlı bir halde ve toplu düzende kuşatmayı yürütüyordu ${ }^{36}$. Bu nitelikteki Haçlıları dağıtmak da sayıca az olan Türk askerlerinin dağınık düzenle çok yönlü saldırılar gerçekleştirmesiyle mümkündü. Türkler hem süratlerini korumak hem de etkili hücumlar yapmak için coğrafî avantajlardan da istifade etmeye çalışmıştır. Buna göre, Türk ordusu

\footnotetext{
31 Willermus Tyrensis, Willermus Tyrensis'in Haçlı Kroniği, 117-118; Albertus Aquensis, Historia Ierosolimitana, 103.

${ }^{32}$ Willermus Tyrensis, Willermus Tyrensis'in Haçlı Kroniği, 118; Albertus Aquensis, Historia Ierosolimitana, 105.

${ }^{33}$ Willermus Tyrensis, Willermus Tyrensis'in Haçlı Kroniği, 116; Albertus Aquensis, Historia Ierosolimitana, 103; Ralph of Caen, The Gesta Tancredi of Ralph of Caen: A History of the Normans on the First Crusade, haz. Bernard S. Bachrach-David. S. Bachrach (Burlington: Ashgate Publishing Company, 2005), 39; Demirkent, Türkiye Selçuklu Hükümdarı Sultan I. Kılıç Arslan, 31.

${ }^{34}$ Willermus Tyrensis, Willermus Tyrensis'in Haçlı Kroniği, 118; Raimundus Aguilers, Haçlılar Kudüs'te: Bir Papazın Gözünden İlk Haçlı Seferi. çev. Süleyman Genç (İstanbul: Yeditepe Yayınevi, 2019), 59.

${ }^{35}$ Albertus Aquensis, Historia Ierosolimitana, 107; Demirkent, Haçlı Seferleri, 32.

${ }^{36}$ Runciman, Haçlı Seferleri Tarihi, 137.
} 
I. Haçlı Seferinde Türkiye Selçuklu Sultanı I. Kılıç Arslan'ın Uyguladığı Savaş Taktikleri ve Türk Ordusunun Savaş̧̧ılık Özellikleri Hakkında Bir Değerlendirme

saldırı emri geldiğinde konuşlandığı yüksek tepeden aşağı doğru taarruza geçecektir ${ }^{37}$. Böylece Türkler sürat ve hareketlilik konusundaki üstünlüklerini mevzi üstünlüğüyle de birleştirerek savaş meydanındaki her türlü imkânı sonuna kadar kullanmaya çalışmışlardır. Raimundus Aguilers, Kılıç Arslan'ın saldırısını başlattığında iki kol halinde Türklerin dağlardan indiğini ve bu iki koldan biri Haçlılarla savaşırken, öteki kolun güney kapısından şehre girmeyi planladığını kaydetmiştir ${ }^{38}$. Tüm bunlara rağmen, Türklerin yaklaşık 4 bin kişilik bir kayba uğradığı bu saldırılar neticesinde Sultan Kılıç Arslan'ın çabaları yetersiz kalmış ve kuşatma yarılamamıştır ${ }^{39}$. Sürecin bundan sonraki akışında bir neticeye ulaşamayan Sultan Kılıç Arslan, ordularına geri çekilme emri vermiştir. Zira o, sayı ve teçhizat yönünden üstün olan Haçlılarla bir meydan savaşı vermenin zor ve boşuna olduğunu anlamıştı. Haçlılar karşısında meydan savaşında ısrarcı olmak daha fazla zayiat anlamına geliyordu ${ }^{40}$. Bundan sonra o, şehirdekilere "Bundan böyle neyi uygun buluyorsanız, onu yapın!" şeklinde bir haber gönderip, onları kendi kaderleriyle baş başa bıraktı ${ }^{41}$. Bununla birlikte sultan, İznik'e göl tarafından birlikler sokmuş ve lojistik destek sağlamıştır ${ }^{42}$. Diğer taraftan sultan, şimdilik terk ettiği meydan savaşını ileride tekrar tatbik etmeyi deneyecektir.

İznik savunması hakkında buraya kadar yapılan değerlendirmeler, kale dışındaki Sultan Kılıç Arslan'ın ordusunun durumu, taktik ve stratejileri hakkında idi. Bunun yanı sıra, kuşatmanın ve buna mukabil savunmanın bir de İznik'i sur içinde savunanlar yönü olduğu malumdur. Şehirde bulunan Türk kumandanları Haçlıların kuşatmayı başlattığını görünce ilk olarak savaşabilecek durumda olanların hazırlanmasını sağlamışlar, şehre ulaşabildikleri her yerden yiyecek sağlamışlar ve şehrin kapılarını tahkim etmişlerdir ${ }^{43}$. Bu savunma hakkında en detaylı bilgileri veren Willermus Tyrensis ve Albertus Aquensis'in kayıtlarından anlaşıldığına göre, şehri savunanların moralleri, özgüvenleri ve savaşçılık özellikleri oldukça yüksektii ${ }^{44}$. Bu durum, İznik'in son derece muhkem olması ile alakalı olmalıdır. Zira İznik surları 11 metre yükseklikte ve $5 \mathrm{~km}$ uzunluğunda olmakla birlikte; bu surları takviye eden 17 metre yüksekliğinde en az 144 en fazla 300 civarı kuleye sahipti ${ }^{45}$. Bundan başka, derin hendekler de mevcuttu ${ }^{46}$. Diğer taraftan, sultanın gelişi, İznik savunucularına yeni bir mücadele azmi kazandırmış; onların cesaret ve ümitlerini son derece artırmıştı ${ }^{47}$. Bu şekilde savunmanın hem maddî unsurlarına hem de insan unsuruna karşı Haçlılar kuşatmayı temelde üç faaliyet üzerinde gerçekleştirmiştir. Bunlar şehir içindeki Türklerin moral ve motivasyonlarını bozmak, ikmal yollarını olabildiğince kesmek ve surları en zayıf noktadan zayıflatarak surda gedik açmaktır. Sur içindeki Türkler aslında Haçlıların bu faaliyetlerine karşı koymada başarı elde etmişlerdi. Zira görüleceği

\footnotetext{
${ }^{37}$ Anonim Haçlı Tarihi, 68.

${ }^{38}$ Raimundus Aguilers, Haçlılar Kudüs'te, 59.

${ }^{39}$ Willermus Tyrensis, Willermus Tyrensis 'in Haçlı Kroniği, 119.

${ }^{40}$ Koca, Türkiye Selçukluları Tarihi: Sultan Alp Arslan'dan Uluğ Keykubad'a (1071-1220), 103; Demirkent, "İznik’in Haçlılar Tarafindan Kuşatılması (6 Mayıs-19 Haziran 1097)”, 32.

${ }^{41}$ Anna Komnena, Alexiad, 326; Koca, Türkiye Selçuklularl Tarihi: Sultan Alp Arslan'dan Uluğ Keykubad'a (1071-1220), 103.

${ }^{42}$ Anna Komnena, Alexiad, 328.

${ }^{43}$ Albertus Aquensis, Historia Ierosolimitana, 95.

${ }^{44}$ Willermus Tyrensis, Willermus Tyrensis 'in Haçlı Kroniği, 115.

45 Demirkent, Türkiye Selçuklu Hükümdarı Sultan I. Kılıç Arslan, 30; Demirkent, "İznik'in Haçlılar Tarafından Kuşatılması (6 Mayıs-19 Haziran 1097)", 21. Araştırmalarda kule sayıları birbirlerinden farklı olarak verilmiştir. Işın Demirkent, kule sayılarını 144 olarak verirken; Steven Runciman, 240 kule olduğundan bahsetmiştir (Runciman, Haçlı Seferleri Tarihi, 136). İznik kuşatmasında bulunan Blois ve Chartres kontu Stephan ise eşine yazdığı mektupta İznik'in 300'ü aşkın kuleye sahip olduğunu belirtmiştir (Abdurrahman Onur Çalışır, Denizaşırı Ülkeden Havadisler: Haçlıların Mektupları (1097-1252) (İstanbul: Kutlu Yayınevi, 2018), 18).

46 Joseph François Michaud, Haçlı Seferlerinin Ilginç Olayları, haz. Güray Kırpık (Ankara: Lotus Yayınevi, 2011), 160.

${ }^{47}$ Koca, Türkiye Selçukluları Tarihi: Sultan Alp Arslan'dan Uluğ Keykubad'a (1071-1220), 103.
} 
I. Haçlı Seferinde Türkiye Selçuklu Sultanı I. K1lıç Arslan'ın Uyguladığı Savaş Taktikleri ve Türk Ordusunun Savaşçılık Özellikleri Hakkında Bir Değerlendirme

üzere, şehri savunanlar Haçlıların psikolojik savaşına aynı şekilde karşılık vermişler, ikmal yolunun kesilmesine son ana kadar müsaade etmemişler ve açılan gedikleri tamir ederek aynı gece içerisinde surları tekrar muhkem hale getirebilmişlerdir.

İlk olarak, Haçlılar İznik'i savunanların moral ve motivasyonlarını bozmak amacıyla kuşatmanın başından sonuna dek birtakım faaliyetlerde bulunmuşlardı. Kuşatmanın başlarında bir grup Haçlı, henüz Kılıç Arslan gelmemişken ve Türk casusları yakalanmamışken, İznik surları altında hakaretler eşliğinde kontrolsüzce saldırılar gerçekleştirerek şehri savunanları galeyana getirmek ve kışkırtmak için ellerinden geleni yapıyorlardı. Ancak bu durum karşısında Türkler sur üstünden attıkları mızraklarla bu faaliyeti gerçekleştiren Haçlı grubunu epey zarara uğratmış ve bilakis Haçlıların morallerini bozmuşlardı. Haçlıların, İznik'i savunan Türkleri yıldırmak için uyguladıkları diğer bir faaliyet ise, şehir dışında Kılıç Arslan ordusunun 4 bin kayıp vererek çekilmesinden sonra, ele geçirilen Türk askerlerinin kesik başlarının bazılarını kazıklara geçirerek Türklerin görebileceği şekilde gezdirmek ve bazılarını şehir surlarından içeri atmaktı ${ }^{48}$. Kuşatmanın daha sonraki akışında hem Sultan Kılıç Arslan'ın çekilmiş olması hem de Haçlıların böyle moral bozucu hamleleri şehri savunanlarda moral ve motivasyon kaybı oluşturmuş olmalıdır.

Şehri savunanların en temel savunma silahı ok ve yay olmakla birlikte onlar, ok ve taş mancınıklarından; muhtelif ağırlıklarda ve büyüklüklerdeki yuvarlanabilen taşlardan; zift, yağ, gres gibi muhtelif türlerdeki yanıcı ve yakıcı maddelerden istifade ediyorlardı. Bu maddeler özellikle iki amaçla kullanılıyordu. İlk olarak, ucu yünle kaplanmış olan tahta parçaları, oluşturulan yanıcı ve yakıcı maddeye batırılıp çıkarılarak ateşe verilmek suretiyle meşale elde ediliyordu. İkinci olarak, bu yanıcı ve yakıcı madde Haçlıların üzerlerine ve kuşatma araçlarına firlatıllyor veya dökülüyordu. Ardından üzerlerine böyle maddeler bulaşmış Haçlı askerlerine ve kuşatma araçlarına daha önceden hazırlanan meşaleler fırlatılıyor ve böylece Haçlı ordularına büyük zararlar veriliyordu ${ }^{49}$. Hatta Michaud'un kaydına göre Türkler, yanıcı ve yakıcı maddeleri ok ve taş atışlarının etkisi artırmak için de kullanıyorlardı. Nitekim yukarıda bahsedildiği şekilde üzerlerine bu maddeler isabet eden Haçlıların kalkan gibi koruyucu teçhizatları alev alınca Türkler, ok ve taş yağmurları başlatmışlardı ${ }^{50}$. Öte yandan Türkler, savunma için taşlardan pek çok yönden istifade etmişlerdi. Buna göre, Türkler taşları Haçlıların üzerine atarak veya yuvarlayarak onları yok etmek için kullandıkları gibi, Haçlıların surlarda gedikler açmaları halinde siper olarak faydalanmak için taşları surların arkasına dizmişlerdi. Bunun yanı sıra şehir savunmasındaki belli bir grup Türk, Haçlıların açmaya çalıştıkları gedikleri yine taşları kullanarak kapatmakla meşgul oluyordu. Hatta Haçlılar Gonatas adlı burcu yıkmak için gündüz açtıkları gediklerin gece kapatıldıklarını görünce umutsuzluğa kapılmışlardı. Ok mancınıkları (balista) ise surların neredeyse her açısına hâkim konuma kurulmuştu ${ }^{51}$.

Haçlıların moralini bozan sadece açılan gediklerin kapatılması değildi. Ayrıca uzun süren kuşatmanın yıpratıcı etkisi ve boşa çıkan mancınık atışlarının üstüne, İznik'i savunan Türklerin yaptıkları savunma ile Haçlıları dikkate değer bir şekilde zarara uğratmaları moral bozukluğunun gittikçe artmasına neden oluyordu ${ }^{52}$. Bütün bunların yanında, Türklerin İznik’i savunmadaki 1srarı,

\footnotetext{
${ }^{48}$ Albertus Aquensis, Historia Ierosolimitana, 95, 109; Raimundus Aguilers, Haçlılar Kudüs'te, 60; Demirkent, Türkiye Selçuklu Hükümdarı Sultan I. Kılıç Arslan, 31; Çalışır, Denizaşırı Ülkeden Havadisler, 21.

49 Willermus Tyrensis, Willermus Tyrensis'in Haçlı Kroniği, 123-124; Albertus Aquensis, Historia Ierosolimitana, 117, 119.

${ }^{50}$ Michaud, Haçlı Seferlerinin Ilginç Olayları, 165.

51 Willermus Tyrensis, Willermus Tyrensis'in Haçlı Kroniği, 120, 122; Anonim Haçlı Tarihi, 68. Albertus Aquensis, Historia Ierosolimitana, 115; Peter Tudebodus, Bir Tanığın Kaleminden Birinci Haçlı Seferi: Kudüs'e Yolculuk, çev. Süleyman Genç (İstanbul: Kronik Kitap, 2019), 78; Raimundus Aguilers, Haçlılar Kudüs'te, 59-60; Demirkent, Türkiye Selçuklu Hükümdarı Sultan I. Kılıç Arslan, 32.

${ }^{52}$ Albertus Aquensis, Historia Ierosolimitana, 115.
} 
I. Haçlı Seferinde Türkiye Selçuklu Sultanı I. Kılıç Arslan'ın Uyguladığı Savaş Taktikleri ve Türk Ordusunun Savaş̧̧ılık Özellikleri Hakkında Bir Değerlendirme

hırsı ve inadı da bunda etkiliydi. Bu hususla ilgili bir kahramanlık ve cesaret örneğini Albertus Aquensis ve Willermus Tyrensis eserlerinde kaydetmişlerdir. Buna göre, kuşatma esnasında şecaati son derece yüksek bir Türk askeri yaralanmış ve buna bağlı olarak hayatından ümidini kesmişti. Elinden kalkanını fırlatıp kalabalık Haçlı grubuna taşlarla saldırarak onlara bir miktar zayiat verdirmişti. İşin ilginç tarafı bu Türk savaşçı bunları yaparken Albertus Aquensis'in anlattı̆̆ına göre, vücuduna yirmi civarı ok saplanmış haldeydi. Aynı vakayı birtakım farklılıklarla anlatan Willermus Tyrensis ise surların üzerindeki iri cüsseli bu Türk savaşçısının ok ve yayı ile bir yandan Haçlılara büyük bir darbe vurduğundan, öte yandan Haçlıları kışkırtmak ve onları tahkir etmek için hakaretler ettiğinden ve "korkaklar!" diye bağırdığından bahsetmektedir. Buna karşılık olarak tahammül sınırının sonuna gelmiş olan Haçlı lideri Godefroi, mezkûr Türk savaşçııı okla kalbinden vurarak durdurmak durumunda kalmıştı ${ }^{53}$. Bu hadise, şehri savunan Türklerin İznik'i kaybetmemek için verdiği mücadeleyi göstermesi bakımından önemlidir.

İznik'in göl tarafının ${ }^{54}$, yani Haçlılar tarafından gemileri olmadığı için kuşatılamayan bu kısmın varlığı da kuşatılanlara bir süre bir avantaj sağlamıştı. Zira Türkler İznik'in göl tarafinı kullanarak şehre kayıklar vasıtasıyla istediği gibi girip çıkıyor; ihtiyacı olan malzemeleri tüccardan tedarik edebiliyor; savaş teçhizatlarını ve hatta sığır gibi büyükbaş hayvanlarını bile Haçlıların gözleri önünde buradan İznik'e sokabiliyorlar ve Sultan Kılıç Arslan'la irtibatlarını bu yolla sağlayabiliyorlardı ${ }^{55}$. Türkler bu üstünlüklerini Bizans' ${ }^{56}{ }^{56}$ kayıklarla müdahalesiyle kaybedene dek Haçlılara karşı etkili bir şekilde kullanmışlardı.

Sultan Kılıç Arslan dışarıdan İznik gölü aracılığıyla destek sağlıyor ve şehir içindeki Türkler dışarıdan her türlü ihtiyacını, bu avantajlarını kaybedene dek, bu şekilde karşılıyor olsalar da bu iş hem riskli hem de zaman alıcı bir faaliyetti. Bu nedenle sur içindekiler için dikkat edilmesi gereken en önemli hususlardan biri eldeki malzemelerin tedarikli kullanılması ve eksilen malzemelerin yerine yenisinin eklenebilmesi idi. Kuşatmada İznik'in güney cephesinde yer alan Fulcherius Carnotensis, bununla ilgili ilginç bir olaydan bahsetmektedir. Onun bahsettiğine göre Türkler, surlar üzerinden kancalı halatları Haçlılara atarak onları surların üstüne çekip onların üzerindeki malzemeleri alıyorlard1 ${ }^{57}$. Vakıayı Willermus Tyrensis ve Albertus Aquensis de doğrulamaktadır. Ancak Fulcherius Carnotensis'ten farklı olarak onlar, bu hadisenin daha çok psikolojik boyutuna değinmişlerdir. Onların bahsettiğine göre, Kont Robert'e tâbi tam teçhizatlı cesur bir şövalye Türklerin geceleyin kapattıkları gediği tekrar açmak için surların altına gelmiş ve epey bir mücadele vermişti. Ancak surların üzerinden sürekli taşlar, mızraklar ve okların atılması ve buna karşılık arkasında hiçbir destek görmemesi, bu şövalyenin mücadelesinde pes etmesine neden olmuştu. Bununla birlikte Türklerin attığı taşlar, mızraklar ve okların yoğunluğuna karşı şövalyenin kalkanı yetersiz kalarak parçalanmıştı. Sonuçta, atılan büyük bir taşın ağırlığına dayanamayarak şövalyenin boynu kırılmış ve o, kayalar altında ezilmişti. Türkler onun cesedini görünce kancaya benzer pençeli bir aparatla surlara çekmişler;

\footnotetext{
${ }^{53}$ Willermus Tyrensis, Willermus Tyrensis'in Haçlı Kroniği, 123; Albertus Aquensis, Historia Ierosolimitana, 119.

${ }^{54}$ İznik'in göl tarafı kuşatanlar için tutulması zor; şartlar oluştuğunda savunanlar için kullanılması kolay doğal bir giriş-çıkış kapısı mahiyetinde idi. Süleyman Şah’ın naibi Ebû’l-Kâsım'ın, Selçuklu emîri Porsuk’a karşı İznik savunmasında Bizans imparatoru Aleksios Komnenos tarafindan gönderilen destek kuvvetleri de bu göl tarafından girmişler ve şehrin ele geçmesini engellemişlerdi (Kesik, At Üstünde Selçuklular, 179-180.)

${ }^{55}$ Willermus Tyrensis, Willermus Tyrensis'in Haçlı Kroniği, 117, 121; Anonim Haçlı Tarihi, 68; Albertus Aquensis, Historia Ierosolimitana, 115; Peter Tudebodus, Bir Tanığın Kaleminden Birinci Haçlı Seferi, 77.

${ }^{56}$ Bizans İmparatorluğunun I. Haçlı seferindeki tavrı ve rolü hakkında başlıca mesela bk: Georg Ostrogorsky, Bizans Devleti Tarihi, çev. Fikret Işıltan (Ankara: Türk Tarih Kurumu Yayınları, 2006), ilgili kısımlar; Alexander A. Vasiliev, Bizans İmparatorluğu Tarihi. çev. Tevabil Alkaç (İstanbul: Alfa Yayınları, 2016), ilgili kisımlar.

${ }^{57}$ Fulcherius Carnotensis, Kudüs Seferi, 67.
} 
onun zırhını ve miğferini almışlar ve onu orada asılı tutarak Haçlıları tahkir etmişlerdi. Bir süre sonra onu tekrar aşağı bırakmışlardı ${ }^{58}$. Mezkûr üç müellifin kaydında görüldüğü üzere, savunma savaş1 yapan Türklerin, Haçlılar karşısında bazı malzemeleri tedarik etme yöntemi oldukça dikkat çekicidir. Zira bu şekilde Türkler şehir savunmasında her türlü malzeme ve teçhizatın son derece önemli olduğunu iyi bildiklerini göstermişlerdir. Ayrıca Türklerin Haçlıların cesaretini kırmak ve onlara gözdağı vermek için her türlü imkânı sonuna kadar kullandıkları görülmektedir. Ancak Türklerin şehir içinden ve dişından vermiş olduğu her türlü mücadeleye rağmen, Bizans'ın İznik gölüne Gemlik körfezinde hazırlanan kayıklar indirmesi ve Haçlılara verdiği destek neticesinde maneviyatları son derece sarsılan Selçuklu savunma birlikleri Bizans'a teslim olmak zorunda kalmıştır ${ }^{59}$. Böylece İznik’i Bizans'a kaptıran Haçlılar, Anadolu'nun içlerine doğru harekâtlarına devam etmişler ve bu süreçte Türkler daimi olarak Haçlilara tacizde bulunmuşlar ve nihayet Eskişehir'de bu sefer büyük bir meydan savaşına çıkmışlardı.

\section{Eskişehir (Dorylaion) Meydan Savaşı (1097)}

Eskişehir'de vuku bulan meydan savaşını iki aşamada ele almak mümkündür. Zira Haçlılar İznik’ten Anadolu içlerine doğru harekete başlamadan evvel ordularını iki gruba ayırmıştı ${ }^{60}$. Birinci grubun kumandanı Bohemond, ikinci grubun kumandanı Raymond de Toulouse idi ${ }^{61}$. Savaşın ilk aşamas1, Türklerin Haçlıların ilk grubuna karşı üstünlüğüyle; ikinci ve son aşaması iki Haçlı grubunun birleşmesine bağlı olarak Haçlıların üstünlüğüyle nihayetlenmiştir. Bu savaşta yenilmelerine rağmen Türklerin Haçlılar karşısında gösterdikleri mücadele Haçlı kaynaklarında dahi takdir edilmiştir.

Sultan I. Kılıç Arslan'ın İznik'te Haçlılar karşısındaki mağlubiyeti ve İznik'i kaybı onun mücadele azmini kırmamıştı. Sultanın İznik’ten çekildikten sonra yaptığı ilk iş, yeni bir ordu toplamaya çalışmak olmuştu. Buna göre, Anadolu'da bulunan Türk beylerine haber göndererek Haçlılara karşı destek istemiş ve Halep, Tarsus, Antakya ve diğer pek çok Anadolu şehrinden gelen askerlerle yeni bir ordu teşkil etme işine girişmişti. Bu sırada gelen istihbaratla Haçlıların iki gruba ayırılıp Eskişehir istikametine doğru hareketi bildirilmişti. Sultan Kılıç Arslan bu istihbarata dayanarak ve Haçlıların iki gruba ayrıldığını firsat sayarak, Danişmendli Gümüş Tegin ve Kayseri hâkimi Hasan Bey'in destek kuvvetlerini de yanına almış ve Suriye civarından gelecek olan desteği beklemeden Eskişehir'de pusu kurmak için harekete geçmişti ${ }^{62}$.

Sultan Kılıç Arslan, tıpkı ordusunu İznik önünde yüksek mevkilere konumlandırdığı gibi; bu defa da Eskişehir civarındaki Sarısu ovasında bulunan tepelere konumlandırdı ${ }^{63}$. Bu konumlandırma düzeni göz önüne alındığında, sultanın pusuya düşürülen Haçlı ordusunu bir sürpriz baskınla alt etmeyi planladığı açıktır. Ayrıca Sultan Kılıç Arslan'ın Haçlıları bu kez daha dikkatli takip ettiği anlaşılmaktadır. Zira sultanın henüz Haçlılar gelmeden Sarısu ovasında pusu kurması, onların nerede konaklayacaklarını ve geceyi nerede geçireceklerini bilerek ya da öngörerek hareket ettiğinin

\footnotetext{
${ }^{58}$ Willermus Tyrensis, Willermus Tyrensis'in Haçlı Kroniği, 123; Albertus Aquensis, Historia Ierosolimitana, $119,121$.

${ }^{59}$ Anna Komnena, Alexiad, 327-330.

${ }^{60}$ Peter Tudebodus, Haçlıların sabahın erken saatlerinde henüz havanın yeterince aydınlanmamasına bağlı olarak rahat yürüyüş için ikiye ayrıldıklarını belirtir (Peter Tudebodus, Bir Tanığın Kaleminden Birinci Haçlı Seferi, 79). Raimundus Aguilers ise bu nedenlerin hiçbirini vermemekle birlikte, ordunun iki gruba ayrılmasını Bohemond'un ve bazı prenslerin lüzumsuz hareketine bağlar (Raimundus Aguilers, Haçlılar Kudüs'te, 63). Anlaşılan Raimundus Aguilers, Haçlı ordusunun iki gruba ayrılmasını desteklememişti.

${ }^{61}$ Anonim Haçlı Tarihi, 71; Albertus Aquensis, Historia Ierosolimitana, 129; Runciman, Haçlı Seferleri Tarihi, 141.

${ }^{62}$ Willermus Tyrensis, Willermus Tyrensis'in Haçlı Kroniği, 130; Demirkent, Haçlı Seferleri, 34; Albertus Aquensis, Historia Ierosolimitana, 131.

${ }^{63}$ Demirkent, Haçl Seferleri, 34.
} 
I. Haçlı Seferinde Türkiye Selçuklu Sultanı I. Kılıç Arslan'ın Uyguladığı Savaş Taktikleri ve Türk Ordusunun Savaşçılık Özellikleri Hakkında Bir Değerlendirme

alametidir. Bu hal birkaç şekilde izah edilebilir. Buna göre, sultan daimi surette casusları vasıtasıyla Haçlıların her hareketini haber alıyordu veya Anadolu coğrafyasına, yani geçiş güzergâhlarına, konak yerlerine hâkim olduğu için Haçlıların Eskişehir'e varacakları zamanın gece olacağını ve bu nedenle orada konaklayacaklarını tahmin etmişti. Ancak savaşın seyri göz önüne alındığında, Sultan Kılıç Arslan, Haçlıların ilk grubuyla ikinci grubunun arasındaki mesafeyi ya öğrenememişti veya baskın yapılacak ilk Haçlı grubunun diğer grupla birleşemeden çabucak yok edileceğini düşünmüş̧ü.

Haçlılar 30 Haziran gecesi Eskişehir'de geceyi geçirmek için ordugâhlarını kurmuşlardı. Haçlıların içinde bulunan Fulcherius Carnotensis, Türklerin Haçlılar için tuzaklar hazırladıklarını ve savaşmak istediklerini öğrendiklerini kaydetmekle birlikte, bu konu hakkında fazla detay vermemektedir. Ancak gece baskın olasıllı̆̆na karşı nöbet tuttuklarını da belirtmiştir ${ }^{64}$. 1 Temmuz sabahında Sultan I. Kılıç Arslan'ın emriyle Selçuklu hücumu başlamıştı. Bu baskın da daha öncekiler gibi okçu atışlarıyla başlatılmış; ardından atlı birlikler harekete geçmişti ${ }^{65}$. Öyle şiddetli ve uzak mesafelerden bir ok atışı başlatılmıştı ki Haçlı kaynakları ok atışlarını yağmur ve doluya benzeterek durumun dehşetini ifade etmeye çalışmışlar; yaralıları kurtarmaya çalışırlarken kendileri yaralıların üzerine ölerek düşmüşler, uzun Kudüs yolculuğu için en önemli araçları olan atlarının çoğunu kaybetmişlerdi ${ }^{66}$. Bu ok atışlarının düzeni ve stratejisi hakkında Willermus Tyrensis'in eserinde geçen bir kayıt fikir vermektedir. Bu kayda göre, Türklerin atışlarının ilk dalgasından ancak kurtulabilenler, ikinci dalgada mutlaka yaralanmaya maruz kalmıştı ${ }^{67}$. Anlaşıldığına göre, Türkler atış yaparken saflar halinde diziliyor; öndeki saf yoğun bir atış gerçekleştirip sadakındaki (okluk) oklar tükenince arkada hazır olan okçular ön safa geçip atışlarını tamamlıyorlardı. Böylece ok atışları yoğun ve aşama aşama gerçekleştiriliyordu. Caen'li Ralph bu savaşta ayrıca çok fazla sayıda mızrak kullanıldığına işaret etmektedir. Hatta öyle ki savaşın ilk aşamasında mızrak saldırısından ölen Haçlıları ateşe konulacak şişlenmiş etlere benzetmişti ${ }^{68}$. Ok ve mızrak saldırılarından sonra Sultan Kılıç Arslan, uzaktan savaşla bu ilk Haçlı grubunun yeteri kadar hırpaladığını anlamış olacak ki, kendilerine arabalarıyla bir korunak yapan Haçlılara karşı bu kez yakından savaş yapmak suretiyle son darbeyi indirmek üzere harekete geçti ${ }^{69}$. Böylece Haçlıların birinci grubunu çember içine alan Türk ordusu zaferi elde etmeye çok yakınken, henüz saldırının başında Bohemond'un öteki Haçlı grubuna gönderdiği haberle, Eskişehir Meydan Savaşı'nın ikinci aşamasını başlatacak olan Haçlıların ikinci grubunun arkadan geldiğinden habersizdi. Bu arada Haçlıların ikinci grubu, Bohemond'dan gelen yardım çağrısının gerçek olduğuna inanamadılar. Zira İznik’te elde ettikleri büyük zaferden sonra Haçlı komutanları Türklerin bir daha göğüs göğüse kendileriyle çarpışamayacaklarını düşünüyorlardı ${ }^{70}$.

Öğle saatlerinde Haçlıların ikinci grubu savaş meydanına intikal edince savaşın ikinci aşaması başlamış oldu. Bu ikinci grup savaş meydanındaki Türklerin nereden geldiklerini merakla büyük bir şaşkınlık yaşarken, Selçuklu ordusunda ise arkadan gelen Haçlı ordusunu görünce cesaret kırılması ve

\footnotetext{
${ }^{64}$ Fulcherius Carnotensis, Kudüs Seferi, 68.

${ }^{65}$ Willermus Tyrensis, Willermus Tyrensis 'in Haçlı Kroniği, 130.

${ }^{66}$ Anonim Haçlı Tarihi, 71; Willermus Tyrensis, Willermus Tyrensis'in Haçlı Kroniği, 131; Fulcherius Carnotensis, Kudüs Seferi, 69; Peter Tudebodus, Bir Tanığın Kaleminden Birinci Haçlı Seferi, 80.

${ }^{67}$ Willermus Tyrensis, Willermus Tyrensis 'in Haçlı Kroniği, 131.

${ }^{68}$ Ralph of Caen, The Gesta Tancredi of Ralph of Caen, 46. Caen'li Ralph Türklerin mizrak kullanmadaki maharetini başka bir vesileyle de belirtmiştir. Ona göre, Haçlılar tarafından 1098 yılında kuşatılan Antakya'da vuku bulan çarpışmada Türkler, Haçlıların arkasından, bir avcının bir geyiği köşeye sıkıştırdığı gibi, mızrak at1yorlard1 (Ralph of Caen, The Gesta Tancredi of Ralph of Caen, 107).

${ }^{69}$ Willermus Tyrensis, Willermus Tyrensis'in Haçlı Kroniği, 132. Caen'li Ralph bu hareketi mıraklı Türk askerlerinin, atlı Haçlı birliklerinden ziyade askerî vasıflardan yoksun sıradan halka yaptığını kaydetmiştir (bk. Ralph of Caen, The Gesta Tancredi of Ralph of Caen, 47.)

${ }^{70}$ Peter Tudebodus, Bir Tanı $\breve{ı n ~ K a l e m i n d e n ~ B i r i n c i ~ H a c ̧ l ı ~ S e f e r i, ~} 81$.
} 
I. Haçlı Seferinde Türkiye Selçuklu Sultanı I. Kılıç Arslan'ın Uyguladığı Savaş Taktikleri ve Türk Ordusunun Savaşçılık Özellikleri Hakkında Bir Değerlendirme

panik baş göstermiştị ${ }^{71}$. Derhal savaşın dengesi değişti. Zira neredeyse tüm umutlarını yitiren ilk Haçlı grubunun moralleri yükselmiş; Haçlı ordusuna büyük kayıplar verdiren Türklerin ise zafere çok yakınken Haçlıların ikinci grubuyla karşılaşması morallerini son derece bozmuştu ${ }^{72}$. Sultan Kılıç Arslan yaşanan ilk şaşkınlıktan bir an evvel çıkmaya çabalamış ve yanına bir miktar asker alarak derhal hâkim bir tepeye çekilmeye ve gelen Haçlıları orada karşılamaya çalışmıştır. Bu şekilde Sultan Kılıç Arslan Haçlıları peşine takarak, 1ssız ve iyi bildiği istikametlere çekip orada imha etmeyi denemiştir $^{73}$. Sultanın bu taktiğini Haçlı müellifleri arasında en mufassal şekilde anlatan Caen'li Ralph’tir. Buna göre, Sultan Kılıç Arslan'ın peşine ilk takılan kişi Dük Godefroi idi. Sultan Kılıç Arslan ilk başta bir tepeye çekip orada dükün ordusunu yok etmek istemişse de Dük Godefroi zor da olsa bu tepeyi ele geçirmiş̧i. Ancak Sultan Kılıç Arslan kendi ordusunun hafif teçhizatlı ve Haçlı ordusunun ağır teçhizatlı olmasından burada da istifade ederek bu sefer daha yükseklere çekilmiş ve uzaktan yağmur gibi ok atışlarıyla; firsatını bulunca da art arda yapılan baskınlarla Dük Godefroi'in ordusuna epey bir zarar vermişti. Burada coğrafî olarak dağ ile ilgili meydana gelebilecek her türlü dezavantaj; süratli atlar, seri ok atışları ve mezkûr müellifin ifadesiyle "Türklerin bundan zevk alması" sayesinde avantaja çevrilmiş görünmektedir ${ }^{74}$. Hatta Blois ve Chartres kontu Stephan, Türklerin İznik'te geri çekilmelerindeki başarısını sarp dağlara bağlar ki bu durum Sultan Kılıç Arslan'ın savaş dehası ve Türk ordusunun savaş kabiliyeti ve dinamizmi ile ilgilidir ve görüldüğü üzere bu durum Eskişehir civarındaki dağlar için de geçerliydi ${ }^{75}$. Ancak sultanın bu çabası da sonuçsuz kalmıştı. Zira bir süre geçtikten sonra Dük Godefroi'e, Büyük Hugue ve Kont Raymond'dan yardım gelmiş; Türkler neredeyse her taraftan kuşatılmaya başlamışt ${ }^{76}$. Bu nedenle avantaj1 ele geçirmiş olan Haçlılar karşısında meydan savaşını devam ettirmenin akıllıca bir hareket olmayacağını idrak etmiş olan Kılıç Arslan, ordusuna geri çekilme emri vermiş ve meydan savaşını gerillâ savaşı tarzıyla değiştirerek Haçlıları istikametleri boyunca yıpratmayı planlamıştı ${ }^{77}$. Savaşın ikinci aşamasının Türkler açısından genel bir başarısızlıkla sonuçlanmasına rağmen Türklerin bu aşamada kısmen uyguladığı birtakım savaş taktikleri dikkat çekmektedir. Caen'li Ralph'in bahsettiğine göre, Haçlıların ikinci grubunda yer alan Büyük Hugue'un birliğine yapılan saldırı her yönden yüksek bir hızla düşmanı daire içine alma ve seri ok atışlarıyla düşmanı bu daire içinde eritme üzerine kuruluydu ${ }^{78}$. Ancak her ne kadar düşman her yönden sarılmış ve ok atışlarına maruz bırakılmışsa da Türkler genel neticede muvaffak olamamıştır.

Sultan Kılıç Arslan'ın Haçlıların hareketlerini son derece itinayla takip etmeye çalışmasına rağmen, bu savaşın kaybedilmesinin temel nedeni, İznik önlerinde oluğu gibi, Haçlıların insan ve teçhizat unsurları bakımından üstünlüğüydü. Zira bu savaşta Haçlı ordusu Sultan Kılıç Arslan'ın tahmin ettiğinden daha kalabalık çıkmış; ayrıca Haçlıların ağır ve sağlam teçhizata sahip olmalarından dolayı hafif teçhizatlı Türk ordusu üstün savaş kabiliyetlerine ve tüm çabalarına rağmen zayıf ve yetersiz kalmışt ${ }^{79}$. Savaşın ilk aşamasında sürpriz baskınla başarı elde eden Sultan Kılıç Arslan'ın

\footnotetext{
${ }^{71}$ Anna Komnena, Alexiad, 332; Peter Tudebodus, Bir Tanığın Kaleminden Birinci Haçlı Seferi, 81; Demirkent, Haçlı Seferleri, 34; Koca, Türkiye Selçukluları Tarihi: Sultan Alp Arslan'dan Uluğ Keykubad'a (1071-1220), 105.

${ }^{72}$ Willermus Tyrensis, Willermus Tyrensis 'in Haçlı Kroniği, 132.

${ }^{73}$ Albertus Aquensis, Historia Ierosolimitana, 135, 137.

${ }^{74}$ Ralph of Caen, The Gesta Tancredi of Ralph of Caen, 54.

${ }^{75}$ Çalışır, Denizaşırı Ülkeden Havadisler, 19.

${ }^{76}$ Ralph of Caen, The Gesta Tancredi of Ralph of Caen, 55.

${ }^{77}$ Turan, Selçuklular Zamanında Türkiye, 131.

${ }^{78}$ Ralph of Caen, The Gesta Tancredi of Ralph of Caen, 51.

${ }^{79}$ Hatta Türklerin hafif teçhizatlarına atıfta bulunan Caen'li Ralph, Haçlı kılıçları karşısında Türk kalkan ve zırhlarının keten iplik gibi dayanıksız olduğunu ifadeyle, bu teçhizatın Türkleri korumaktan ziyade onlara yük olduğunu belirtmiştir (Ralph of Caen, The Gesta Tancredi of Ralph of Caen, 52).
} 
I. Haçlı Seferinde Türkiye Selçuklu Sultanı I. Kılıç Arslan'ın Uyguladığı Savaş Taktikleri ve Türk Ordusunun Savaş̧̧ılık Özellikleri Hakkında Bir Değerlendirme

ordusu, ikinci aşamada Haçlıların ikinci grubunun bir nev'i sürpriz baskınıyla mağlup olmuştur denilebilir. Buna rağmen Türklerin üstün savaş yetenekleri ve zafer elde etmek üzerine gösterdikleri gayretler, Haçlı kaynaklarında bile övgüyle kaydedilmiştir. Zaten Anonim Gesta müellifi ve Peter Tudebodus, şayet Haçlı ordusunun ikinci grubu gelmeseydi mutlak surette Türklerin zaferi elde edeceğini kaydetmiştir. Bu kayıttan başka, dikkat çekici bir deyişi de nakleden aynı müellifler savaştaki cesaretleri, silah kullanmadaki becerileri meşhur olan Türklerin Franklarla aynı kökenden geldiğini ve yine Franklarla Türklerden başka hiçbir insanın doğuştan şövalye olamayacağını belirtmişlerdir. Mezkûr müellifler bu deyişi naklettikten sonra kendi yorumlarını belirtmekten de geri durmamış ve Türkler Hristiyan olsalardı yeryüzünde onlardan daha güçlü askerler olmayacağını ve mağlubiyete uğramayacaklarını da itiraf etmişlerdir ${ }^{80}$. Türklerden hiç hoşlanmayan Fulcherius Carnotensis bile Türklerin savaş sanatındaki ustalığını kabul ve itiraf etmiş görünmektedir. Ona göre, Türklerin savaş tarzına ve mücadele azmine alışık olmadıklarından Haçlılar büyük bir şaşkınlığa uğradılar ve "Gerçek korkuyu bilmeyen Türklerin cüreti ve cesareti dikkat çekiciydi." Hatta Fulcherius Carnotensis'in şu kaydı, Anonim Gesta müellifinin savaşın şiddetini tasvir eden kayıtlarını doğrular niteliktedir: "Artık günahkârların mahkemesinde sanık olduğumuzu kabul ederek Tanrı'dan merhamet diliyorduk." Bu kayıt, Haçlıların ilk grubunun savaştan galibiyet ümidini kesmiş olduğunu ve artık sadece Tanrı'ya yapılacak dua neticesinde kurtuluşa erişebileceklerine inandıklarını göstermektedir. Ayrıca dolaylı da olsa Türklerin Haçlılar üzerine Tanrı'nın cezası olarak gönderildiğine inanılmaya başlandığını da göstermektedir ${ }^{81}$. Albertus Aquensis'in kayıtlarına göre ise Türklerin aralıksız devam eden taarruzları sonucunda Haçlı karargâhındaki kadın-erkek, yaşl1-genç herkes büyük bir dehşete kapılmış ve hatta genç kadınlar güzelliklerini kullanarak Türklerin muhtemel affına sığınmaya çalışmışlardır ${ }^{82}$. Bu kayıtlar tarihî kaynakların kaydedebileceği nadir kayıtlardandır. Zira tarihçilerin rakip milletleri, hem de savaş halinde oldukları rakiplerini takdir etmeleri pek alışılagelmiş bir durum değildir. I. Haçlı seferinin ele alınan bütün bu safhaları hakkında genel bir sessizlik içinde bulunan Doğu kaynakları bile kısa da olsa savaşın şiddetini "yeryüzünün titrediği, okların yağmur olduğu, katliamın had safhaya ulaştı̆̆ 1 " şeklinde ifadelerle aktarmıştır ${ }^{83}$.

Yukarıda değerlendirilen bütün savaşların neticesinde Sultan I. Kılıç Arslan Haçlı ordularını meydan savaşıyla yok edemeyeceğini anlamış ve bu durum bir taktik değişikliği gereksinimini ortaya çıkarmıştı. Artık düzenli ordu savaşlarından gerillâ savaşlarına geçiş yapmanın zorunluluğu anlaşılmış ve Türk ordusu geri çekilmişti ${ }^{84}$. Ancak bu geri çekilmeyle birlikte yapılan taktik değişikliğin neticesi olarak Türkler Haçlıların güzergâhlarında bulunan her türlü ikmal ve iaşe madde ve malzemelerini kullanılamaz hâle getiriyorlar veya yok ediyorlardı. Bundan amaç Haçlı ordusunu maddeten ve manen yıldırmak, yıpratmak ve böylece takatten düşürüp, uygun bir yerde, son bir darbe vurmak suretiyle sonuca gitmekti ${ }^{85}$. Nitekim bu faaliyetler neticesinde yolda Haçlllar açlık ve susuzluk çekmelerinin yanı sıra onların atları telef olmuş, pek çok şövalye yola yaya olarak veya öküzler üzerinde devam etmek zorunda kalmıştı ${ }^{86}$. Böylece Kılıç Arslan'ın yıldırma ve yıpratma taktiğinin son derece başarılı

\footnotetext{
${ }^{80}$ Anonim Haçlı Tarihi, 73-74; Peter Tudebodus, Bir Tanı̆̆ın Kaleminden Birinci Haçlı Seferi, 82-83.

${ }^{81}$ Fulcherius Carnotensis, Kudüs Seferi, 69.

${ }^{82}$ Albertus Aquensis, Historia Ierosolimitana, 131, 133.

${ }^{83}$ Urfalı Mateos, Urfalı Mateos Vekayi-nâmesi (952-1136) ve Papaz Grigor'un Zeyli (1136-1162), çev. Hrant D. Andreasyan (Ankara: Türk Tarih Kurumu Yayınları, 2000), 190. Eskişehir (Dorylaion) meydan savaşı ile ilgili ayrıca mesela bk. Birsel Küçüksipahioğlu, "Sultan I. Kılıç Arslan'ın Eskişehir Yakınında Haçlılara Karşı Büyük Mücadelesi: Dorylaion Savaşı (1 Temmuz 1097)”. Tarih ve Uygarlık İstanbul Dergisi 4 (Aralık 2013), 135-144.

${ }^{84}$ Koca, Türkiye Selçukluları Tarihi: Sultan Alp Arslan'dan Uluğ Keykubad'a (1071-1220), 106.

${ }^{85}$ Koca, Türkiye Selçukluları Tarihi: Sultan Alp Arslan'dan Uluğ Keykubad'a (1071-1220), 106.

${ }^{86}$ Runciman, Haçlı Seferleri Tarihi, 144-145; Turan, Selçuklular Zamanında Türkiye, 132; Peter Tudebodus, Bir Tanı ̆̆ın Kaleminden Birinci Haçlı Seferi, 85.
} 
I. Haçlı Seferinde Türkiye Selçuklu Sultanı I. K1lıç Arslan'ın Uyguladığı Savaş Taktikleri ve Türk Ordusunun Savaşçılık Özellikleri Hakkında Bir Değerlendirme

olması sayesinde Haçlılar Konya Ereğlisi'nden itibaren bir grubu Antakya ve bir grubu Kayseri'ye kadar büyük zayiata uğradıktan sonra Kudüs istikametinde Anadolu'dan ayrılacaklardır.

\section{SONUC}

Türkiye Selçuklu sultanı I. Kılıç Arslan, Haçlılara karşı ağır bir vatan savunması gerçekleştirmiştir. O, başkomutanlık özellikleri ve emrindeki Türk ordusunun silah kullanmadaki yeteneği ve üstün mücadele azmi sayesinde Haçlı istilasında büyük kuvvet kaybına uğramamasına rağmen, başşehri yaptığı İznik başta olmak üzere önemli bölgelerini Haçlılara ve Bizans İmparatorluğuna kaptırarak çekilmek durumunda kalmıştır. I. Kılıç Arslan Haçlılar karşısında kararında, tutumunda direnen bir tavır sergilemiştir. Haçlı ordularını tamamen imha edememesine ve Haçlıların sayıca ve teçhizatça üstünlüğüne rağmen, kısa süreli yaşanan panikler bir yana, Kılıç Arslan'ın mücadele azmi ve cesareti kırılmamıştır. Bunun yanında bilhassa Haçlı öncülerine karşı elde ettiği dar kapsamlı galibiyetler neticesinde rehavete kapılması, onu birtakım stratejik hatalara sürüklemiştir. Diğer taraftan o, durum ve şartlara göre ani ve isabetli kararlar verebilmiş ve yeni taktik ve stratejiler geliştirebilmiş; Türk orduları da bunları tam bir kavrayışla başarıyla uygulayabilmiştir. Ele alınan süreçte Kserigordon, İznik, Kırkgeçit (Drakon) ve Eskişehir'de (Dorylaion) Haçlı ordularına karşı Türkiye Selçuklu sultanı I. Kılıç Arslan başkomutanlığındaki Türk orduları başlıca meydan, kuşatma, savunma ve gerillâ savaşları vermiştir. Bu savaş türleri dâhilinde, ilgili savaşın gerektirdiği maddî ve manevî cepheleri haiz bütün faaliyet ve unsurlardan olabildiğince yararlanılmıştır. Sultan I. Kılıç Arslan ve Selçuklu ordusu Haçlılara karşı iklimsel ve coğrafî olanakları da hem savaş öncesince, hem savaş sırasında ve hem de savaş sonrasında kullanmıştır. Özellikle sürpriz baskın ve hücum için ormanlık ve dağlık alanlar; yıpratmak ve yıldırmak için engebeli arazilerin sunduğu olanaklardan istifade edilmiştir. Kırkgeçit’te ormanların, İznik'te yüksek tepelerin, Eskişehir'de tepelerle birlikte bilhassa geri çekilirken engebeli arazilerin tercih edilmesi bunu göstermektedir. Gecenin karanlığı ve yaz mevsiminin aşırı sıcağı da lehte kullanılmıştır. Eskişehir'de pusu kurulurken gecenin karanlığından faydalanılmıştır. Yüksek sıcaklıkların yaşandığı yaz döneminde Anadolu'nun ortasından güneyine kadar Haçlı ordularının su ihtiyaçlarını ve diğer iaşelerini giderebilecekleri kaynakların kesilmesi, zaten yıpratılmış Haçlı ordusunun yol boyunca açlık ve susuzlukla mücadele etmesini sağlamıştır ki Haçlılar Antakya'yı ele geçirene kadar bu durumun zorluklarını yaşamışlardır. Hatta Haçlıların susuzluklarını ve açlıklarını giderebilmek için mecbur kaldıkları tutum ve davranışlar ibretle tarih kitaplarına konu olmuştur.

Müslüman Türkler ile Hristiyan Haçlılar ilk kez I. Haçlı seferinde karşı karşıya gelerek, birbirlerini tanıma fırsatı bulmuşlardır. Türklerin başlıca silahı olan ok, ilk kez ağır zırhlarla bürünmüş olan Haçlılara karşı, kısmî başarılar bir yana, genel itibariyle yeteri kadar etkili olamamıştır. Diğer taraftan Haçlılar da daha ilk temaslardan itibaren Türklerin savaşçılık niteliklerini, cesaretlerini ve yiğitliklerini görüp takdir etmişlerdir. Haçllları ilk tecrübe eden Müslüman ve Türk hükümdarı olarak Kılıç Arslan ve ordusu böylece bu tanımanın bedelini de ödeyenler olmuştur. Bu bedelin karşılığında Haçlıların savaşçılık özelliklerini ve savaş tarzlarını öğrenen Türkler onlarla uzun bir süre daha çatışma halinde bulunsalar da ağır sonuçları olan yenilgiyle karşılaşmayacaklardır. Aksine Sultan I. Kılıç Arslan 1100 ve 1101 yıllarında arka arkaya Anadolu’ya gelen Haçlı ordularını tamamen imha edecek $^{87}$; Haçlılara karşı verilen başarılı savaşlar öteki Haçlı seferlerinde de devam edecektir. Bununla birlikte, İslâm dünyasını muhafaza eden en önemli seti, yani Anadolu Türklerini az veya çok zayiatla aşan Haçlılar Urfa, Antakya, Trabluşşam ve Kudüs’te kurdukları devletlerle uzun yıllarca Orta Doğu ve Anadolu'da askerî ve siyasî önemli roller oynayacaklardır.

\footnotetext{
${ }^{87}$ Sultan I. Kılıç Arslan'ın Haçlılarla mücadelesi hususunda ayrıca mesela bk. Birsel Küçüksipahioğlu, "The First Turkish Leader against the Crusaders: Sultan Kilij Arslan I”, Şarkiyat Mecmuası 26 (Ocak 2015), 63-83.
} 
I. Haçlı Seferinde Türkiye Selçuklu Sultanı I. Kılıç Arslan'ın Uyguladığı Savaş Taktikleri ve Türk Ordusunun Savaşçılık Özellikleri Hakkında Bir Değerlendirme

Author Contributions / Yazarların Katkısı: This article is a work with two-authors. The contribution of the aforementioned authors to the preparation of the article is equal. / Bu makale, iki yazarlı bir eserdir. Makalenin hazırlanmasına söz konusu yazarların katkısı eşittir.

Funding / Finansman: This research received no external funding. / Bu araştırma herhangi bir dış fon almamıştır.

Conflicts of Interest / Çıkar Çatışması: The author declare no conflict of interest. / Yazar, herhangi bir çıkar çatışması olmadığını beyan eder.

\section{KAYNAKÇA}

Albertus Aquensis. Historia Ierosolimitana: History of the Journey to Jerusalem. İng. çev: Susan B. Edgington. Oxford: Oxford Medieval Text, 2007.

Anna Komnena. Alexiad. çev. Bilge Umar. İstanbul: İnkılap Kitabevi, 1996.

Anonim Haçlı Tarihi. çev. Ergin Ayan. İstanbul: Selenge Yayınları, 2013.

Asbridge, Thomas. Haçlı Seferleri. çev. Ekin Duru. İstanbul: Say Yayınları, 2014.

Barber, Malcolm. Haçlı Devletleri Tarihi. çev. Doğan Mert Demir. İstanbul: Kronik Kitap, 2021.

Cahen, Claude. Haçlı Seferleri Zamanında Doğu ve Batı. çev. Mustafa Daş. İstanbul: Yeditepe Yayınevi, 2016.

Çalışır, Abdurrahman Onur. Denizaşırı Ülkeden Havadisler: Haçlıların Mektupları (1097-1252). İstanbul: Kutlu Yayınevi, 2018.

Demirkent, Işın. "İznik'in Haçlılar Tarafından Kuşatılması (6 Mayıs-19 Haziran 1097)". Haçlı Seferleri Tarihi: Makaleler, Bildiriler, Incelemeler. İstanbul: Dünya Yayınc1l1k, 2012, s. 21-42.

Demirkent, Işın. Haçlı Seferleri. İstanbul: Dünya Yayıncılık, 2013.

Demirkent, Işın. Türkiye Selçuklu Hükümdarı Sultan I. Kılıç Arslan. Ankara: Türk Tarih Kurumu Yayınları, 2014.

Frankopan, Peter. The First Crusade: The Call from the East. Massachusetts: Belknap Press of Harvard University Press, 2012.

Fulcherius Carnotensis. Kudüs Seferi. çev. İlcan Bihter Barlas. İstanbul: IQ Kültür Sanat Yayıncılık, 2009.

Göksu, Erkan. "Haçlıların Anadolu'daki İlk Faaliyetleri ve Kırkgeçit (Drakon) Savaşı (1096)". Ekev Akademi Dergisi. 39 (Bahar 2009), s. 363-370.

Göksu, Erkan. Türkiye Selçuklularında Ordu. Ankara: Türk Tarih Kurumu Yayınları, 2010.

Hillenbrand, Carole. Müslümanların Gözünden Haçlı Seferleri. çev. Nurettin Elhüseyni. İstanbul: Alfa Yayınları, 2015.

İbn Kalânisî. Şam Tarihine Zeyl: I. ve II. Haçlı Seferleri Dönemi. çev. Onur Özatağ. İstanbul: Türkiye İş Bankası Kültür Yayınlar1, 2015.

Kesik, Muharrem. At Üstünde Selçuklular: Türkiye Selçukluları'nda Ordu ve Savaş. İstanbul: Timaş Yayınları, 2014.

Koca, Salim. Selçuklular'da Ordu ve Askerî Kültür. Ankara: Berikan Yayınevi, 2005.

Koca, Salim. Türkiye Selçukluları Tarihi: Sultan Alp Arslan'dan Uluğ Keykubad'a (1071-1220). Ankara: Berikan Yayınevi, 2016.

Küçüksipahioğlu, Birsel. "Sultan I. Kılıç Arslan'ın Eskișehir Yakınında Haçlılara Karşı Büyük Mücadelesi: Dorylaion Savaşı (1 Temmuz 1097)". Tarih ve Uygarlık Istanbul Dergisi 4 (Aralık 2013), 135-144.

Küçüksipahioğlu, Birsel. "The First Turkish Leader against the Crusaders: Sultan Kilij Arslan I". Şarkiyat Mecmuası 26 (Ocak 2015), 63-83.

Küçüksipahioğlu, Birsel. "Türklerle Haçlıların İlk Karşılaşması: Drakon Savaşı". Tarih ve Uygarlık İstanbul Dergisi 3 (May1s-Haziran 2013), 43-51.

Michaud, J. F. Haçlı Seferlerinin Illginç Olayları. haz. Güray Kırpık. Ankara: Lotus Yayınevi, 2011.

Munro, Dana Carleten. Urban and Crusaders. Philadelphia, Pa.: The Department of History of the University of Pennsylvania, 1901.

Ostrogorsky, Georg. Bizans Devleti Tarihi. çev. Fikret Işıltan. Ankara: Türk Tarih Kurumu Yayınları, 2006.

Peter Tudebodus. Bir Tanığın Kaleminden Birinci Haçlı Seferi: Kudüs'e Yolculuk. çev. Süleyman Genç. İstanbul: Kronik Kitap, 2019.

Raimundus Aguilers. Haçlılar Kudüs'te: Bir Papazın Gözünden İlk Haçlı Seferi. çev. Süleyman Genç. İstanbul: Yeditepe Yayınevi, 2019.

Ralph of Caen. The Gesta Tancredi of Ralph of Caen: A History of the Normans on the First Crusade. haz. Bernard S. Bachrach-David S. Bachrach. Burlington: Ashgate Publishing Company, 2005.

Rice, Tamara Talbot. Anadolu Selçuklu Tarihi. çev. Tuna Kaan Taştan. Ankara: Nobel Akademik Yayıncılık, 2015.

Riley-Smith, Jonathan. The First Crusade and the Idea of Crusading. London: Continuum, 2003.

Runciman, Steven. Haçlı Seferleri Tarihi. çev. Fikret Işıltan. I. Cilt. Ankara: Türk Tarih Kurumu Yayınları, 4. Baskı, 2008

Turan, Osman. Selçuklular Zamanında Türkiye. İstanbul: Ötüken Neşriyat, 2004.

Urfalı Mateos. Urfalı Mateos Vekayi-nâmesi (952-1136) ve Papaz Grigor'un Zeyli (1136-1162). çev. Hrant D. Andreasyan. Ankara: Türk Tarih Kurumu Yayınları, 3. Bask1, 2000.

Usta, Aydın. Haçlı Seferlerinde Kuşatma. İstanbul: Yeditepe Yayınevi, 2015.

Vasiliev, Alexander A.. Bizans İmparatorluğu Tarihi. çev. Tevabil Alkaç. İstanbul: Alfa Yayınları, 2016.

Willermus Tyrensis. Willermus Tyrensis'in Haçlı Kroniği: Başlangıçtan Kudüs'ün Zaptına Kadar. çev. Ergin Ayan. İstanbul: Ötüken Neşriyat, 2016. 